\title{
The Effect of Service Quality, Satisfaction and Loyalty toward Customer Retention in the Telecommunication Industry
}

\section{Voon Sze Chee, Maizaitulaidawati Md Husin}

To Link this Article: http://dx.doi.org/10.6007/IJARBSS/v10-i9/7496

DOI:10.6007/IJARBSS/v10-i9/7496

Received: 08 June 2020, Revised: 04 July 2020, Accepted: 20 August 2020

Published Online: 16 September 2020

In-Text Citation: (Chee, \& Husin, 2020)

To Cite this Article: Chee, V. S., \& Husin, M. M. (2020). The Effect of Service Quality, Satisfaction and Loyalty toward Customer Retention in the Telecommunication Industry. International Journal of Academic Research in Business and Social Sciences. 10(9), 55-71.

\section{Copyright: (C) 2020 The Author(s)}

Published by Human Resource Management Academic Research Society (www.hrmars.com)

This article is published under the Creative Commons Attribution (CC BY 4.0) license. Anyone may reproduce, distribute, translate and create derivative works of this article (for both commercial and non-commercial purposes), subject to full attribution to the original publication and authors. The full terms of this license may be seen at: http://creativecommons.org/licences/by/4.0/legalcode

Vol. 10, No. 9, 2020, Pg. 55 - 71 


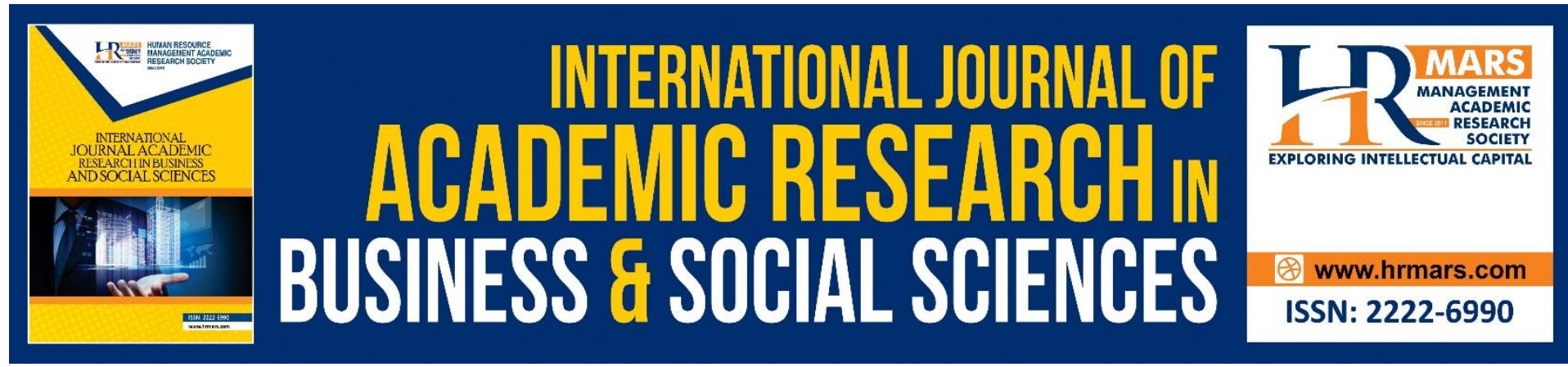

\title{
The Effect of Service Quality, Satisfaction and Loyalty toward Customer Retention in the Telecommunication Industry
}

\author{
Voon Sze Chee, Maizaitulaidawati Md Husin \\ Azman Hashim International Business School, Universiti Teknologi Malaysia, Kuala Lumpur, \\ Malaysia \\ Email: erskine2020@gmail.com, maizaitulaidawati@gmail.com
}

\begin{abstract}
Telecommunication industry becomes more competitive, and mobile service providers are facing challenges in maintaining their customer. As a customer plays a vital role in business growth, a company must retain their customer. Thus, the purpose of this research is to examine the effect of service quality, satisfaction and loyalty towards customer retention a telecommunication industry in Malaysia. Data has been collected using a survey questionnaire and analyzed using SPSS and Smart-PLS. Six of the hypotheses were supported. Customer satisfaction has been found to have a significant relationship with customer loyalty. Service quality, which was measured using the network, customer service, and pricing structure, has been found to have a significant relationship with customer satisfaction. Research implications and recommendations are further discussed.
\end{abstract}

Keywords: Service Quality, Customer Satisfaction, Customer Loyalty, Customer Retention, Telecommunication Industry, Malaysia

\section{Introduction}

In the past few decades, the telecommunication industry in the Asia region, including in Malaysia, has been experienced tremendous growth (Chang et al., 2011). In Malaysia, the first telecommunication company that provides fixed-line service in the country - Telekom Malaysia was founded back in 1984. Since then, many companies such as Maxis, Celcom, Digi, and $U$ Mobile that have been emerged in Malaysia to serve the high demand and sophisticated request from customer on the wireless services (Chuah et al., 2015; Munyanti et al., 2018). From the recent report by the Malaysian Communication and Multimedia Commission (SKMM, 2018), the telecommunication sector revenue had been grown about $3.7 \%$ to RM35.86 billion in 2018 from RM34.58 billion in 2017. According to SKMM (2018), the mobile service providers have been contributed approximately $64 \%$ to the overall revenue in the telecommunication industry. In term of market share, it has been found that mobile service providers successfully captured more than half of the market compared to the fixed service provider. This situation arises due to customer needs data mobility service with highspeed data communication that associated high tech smartphone usage while they move around. 


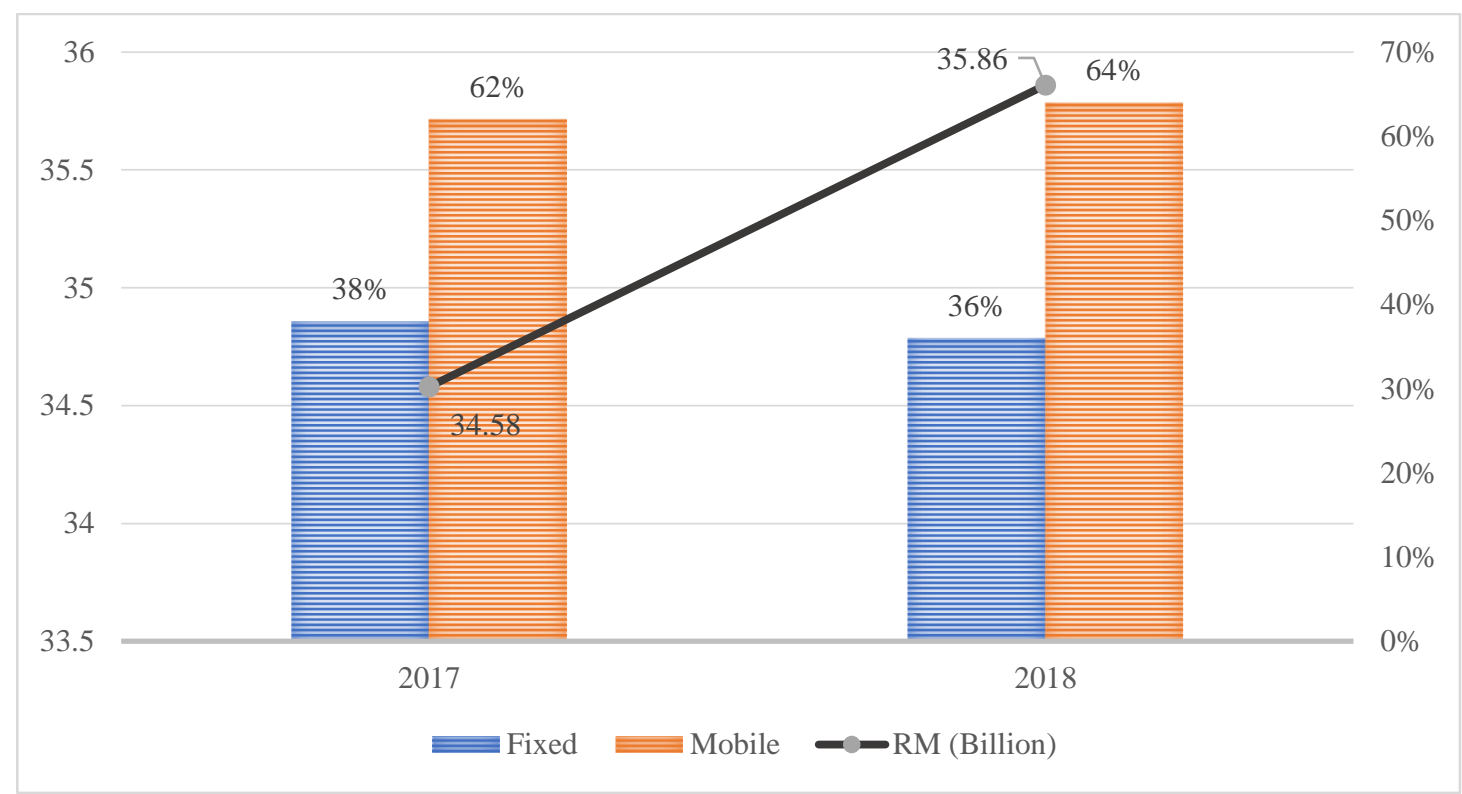

Figure 1: Telecommunication Sector Revenue 2018 vs 2017 (SKMM, 2018)

Digi, Maxis, Celcom and Umobile are among few major players in the telecommunication industry in Malaysia, and they compete to sustain their base customer from the competitors. The market share of Digi, Maxis, Celcom and Umobile is depicted in Figure 2. In 2009, the market share was dominated by Maxis, Celcom and Digi. However, it has been declined dramatically due to new entry of player (U Mobile) and or the introduction of Mobile Virtual Network Operators (MVNOs) that is gaining ground that took about $16 \%$ and $12 \%$ respectively on 2018. Apart from that, the trend line has been started decrease partly was due to the launching of the Mobile Number Portability (MNP) in October 2008 (MCMC, August 2008) whereby the existing users in current service provider able to maintain their existing number while switching around their service provider (Chuah \& Mohd, 2011; Bernama, 2008).

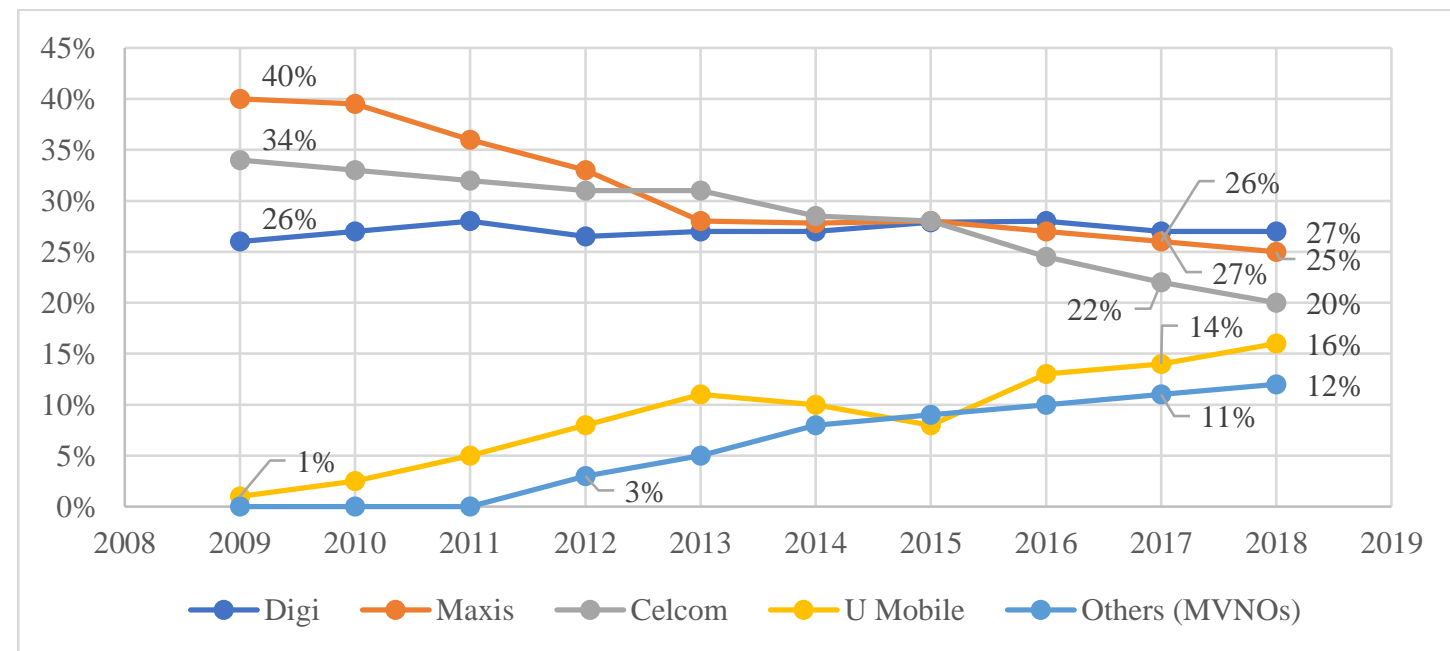

Figure 2: Mobile Cellular Subscriptions Market Share by Service Providers 2009 - 2018

(SKMM, 2018)

The implementation of MNP affected the industry players, and they tried to retain their base customer to maintain their market share. However, the introduction of MNP gives the customer the freedom to switch from one to another service provider (Danish et al., 2015). 
Thus, it becomes essential for the company to ensure customer satisfaction, loyalty and retention (Chuah \& Mohd, 2011). A conceptual model proposed in this research attempts to show that relationships between service quality and customer satisfaction, loyalty, and retention exist. It is envisaged that conceptual models in service quality enable the telco to plan their marketing strategy and design a quality improvement program thereby improving the efficiency, profitability and overall performance of the company. Based on the above, this research, therefore, aims to answer the following research questions (Table I) and objectives (Table II). This research

Table I: The research question

RQ1 Does service quality have a significant relationship with customer
satisfaction?
RQ2 Does customer satisfaction have a significant relationship with
customer loyalty?
RQ3 Does customer loyalty have a significant relationship with customer
retention?

Table II: The research objective

RQ1

To examine the relationship between service quality and customer satisfaction.

RQ2 To examine the relationship between customer satisfaction and customer loyalty.

RQ3 To examine the relationship between customer loyalty and customer retention.

\section{Literature Review}

Telecommunication industry in Malaysia

The first telecommunication company- Telekom Malaysia, had been found back in 1984 . Since then, newcomers joined the industry with the issuance of six new licenses in late 1993 (Mohamad, 2004). Since then, the industry is growing in tandem with robust technology. The introduction of smart devices further enhances the industry especially when web-based application messenger such as Skype, Whatapps, LINE, Telegram, WeChat successfully entered the market and made conventional voice call and short message service (SMS) left behind. As can be seen in figure 3 below, mobile cellular has gain popularity in comparison to direct exchange line (DEL) for the last 20 years (SKMM, 2018). 


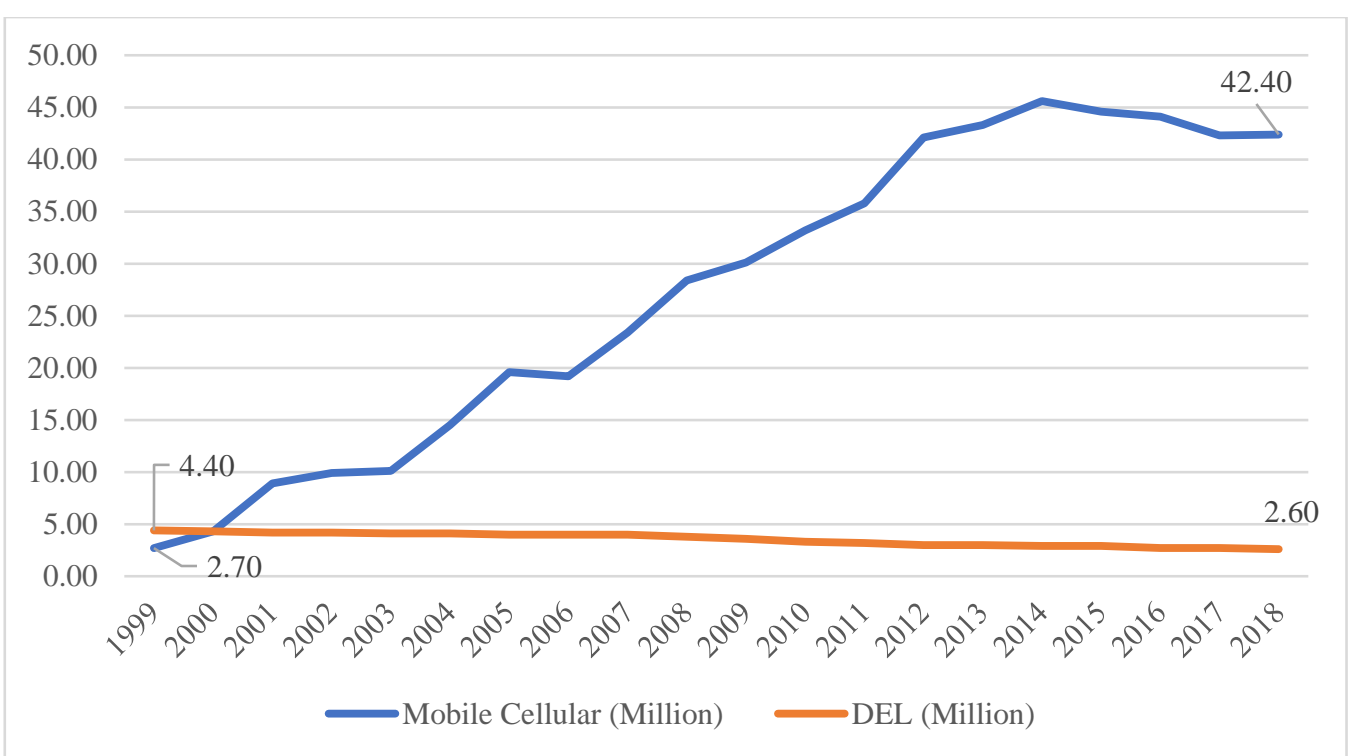

Figure 3: Communication Services Developments (Direct Exchange Line (DEL) vs mobile Cellular) $1999-2018$ (SKMM, 2018)

\section{Customer Retention}

The word customer retention describes the service provider able to fulfil the customer expectation, and further maintain it in the long-term relationships to guarantee the long-term buying decisions (Otaigbe, 2018, \& Preikschas et al., 2017). Previous studies found that repurchase intent was the main benefit of customer retention (Silva \& Yapa, 2013). According to Silva \& Yapa (2013), the service provider should always govern the customer satisfaction and customer loyalty to ensure customer retention. By ensuring satisfaction and loyalty, it is easier to retain the customer from choosing products and services from other competitors (Ocloo \& Tsetse, 2013). Jeng, \& Bailey, (2012) said that, in the telecommunication industry, where the service provider provides a service contract with attractive price tag able to retain their customer for a specified duration of time.

\section{Customer Loyalty}

Customer loyalty is defined as an attitude to brand preference, commitment and intentionto-buy (Lee \& Feick, 2001). Loyalty has lead to the strong desire of repurchase to the same brand or service due to the positivity toward the particular organization (Danish et al., 2015). According to Ndubisi (2005), the loyalty of a customer towards a specific brand or company can be enhanced by providing a gift, discount voucher, and freebies during the event or festival for encouraging the repurchase intention. Therefore, it's vital that an organization able to sustain in the competitive market jointly profitable associates with the customer by developing customer loyalty (Khan, 2012, Pan et al., 2011). Silva \& Yapa (2013); Jeng et al., (2012) \& Gerpott et al. (2001) mentioned that customer loyalty and satisfaction are an integral part of customer retention process. Various research has been measured the relationship between customer loyalty and customer retention. For example, Danish et al. (2estimateasure the relationship of customer loyalty and customer retention at the Pakistan telecommunication industry. Khaligh et al. (2012), found the same in the Iranian telecommunication industry. Thus, this research hypothesizes that customer loyalty has had a significant relationship with customer retention. 


\section{Customer Satisfaction}

Customer satisfaction refers to the customers overall evaluation of patronage experience (Loke et al., 2011). It can also be defined as the overall retrospective judgment about how far the customer expectations concerning service have been fulfilled in the use of situations (Gerpott et al., 2001). Some researchers found that high customer satisfaction will lead to repeat visitation to store, repurchases, and also encourage positive word-of-mouth" (Fornell et al., 1994; Wirtz, 2003). In contrast, a customer with dissatisfactory will always as associate with frustration feeling (Zeithaml et al., 1996). Kotler, \& Amstrong, (2010) said that "A satisfied customer often stays loyal longer, and is likely to patronize the firm in the future". The positive and significant relationship between customer satisfaction and customer loyalty has been found in many studies (Lim et al., 2006; Aydin et al., 2005; Gerpott et al., 2001; Lee et al., 2001; Kim et al., 2004). In the telecommunication industry, for example, Lim et al. (2006) has been conducted research to validate customer satisfaction of US general subscribers. In Turkey, Korea and Nigeria, Aydin et al. (2005); Kim et al. (2004); Oladapo (2018) also measure the satisfaction of the customer at the telecommunication industry.

\section{Service Quality}

In the context of telecommunication industry, service quality can be measured in six different dimensions; the network service, the mobile devices, the customer service, the value-added services, the pricing structure and the billing system provided by the company. Shafei et al. (2016), Santouridis et al. (2010) and Kim et al. (2004) also categorized these dimensions in measuring service quality in various countries such as Egypt, Greece and Korea.

Network or also known as network quality is measured by the frequency of drop calls, voice quality, and coverage (Santouridis et al., 2010; Lim et al., 2004). To measure the voice quality, loudness, the level of distortion during the conversation, and the tone quality of the voice are taken into consideration (Shafei et al., 2016; Santouridis et al., 2010; Kim et al., 2004; Aydin et al., 2005; Lim et al., 2006). In most cases, the customer will be offered a subsidized mobile device while subscribing the mobile plan, which able to attract potential customer (Shafei et al., 2016). In measuring service quality, the mobile devices are evaluated based on the quality, variety and design of the device (Shafei et al., 2016; Santouridis et al., 2010; Aydin et al., 2005).

In the telecommunication service context, customer service is evaluated by the skills or ability of a company to provide a service or product as promised to the customer (Munyanti, \& Mastrom, 2018). Jeng et al. (2012), said that the service provider should provide comprehensive solutions while offering the products and services to the customer. Therefore, customer service quality to be determined by the customer representative skills set levels such as the knowledge, courteous, excellent listening skills, and willingness to compromise to resolve the problem (Investopedia, 2016). In addition to that, it is also referred to the customer support system, the process of complaint handling system and also userfriendliness of complaint reporting (Kim et al., 2004). Tripathi et al. (2009) said that most customer would be dissatisfied if the customer service that has been provided is not up to their expectation. Conventional voice service such as caller tunes or customized ringtones, astrology topics and daily news update is the value-added service offered by the company (Tripathi et al., 2009). Some researcher has included the precision of billing service, and the ease of access service provider as part of the value-added service (Lee et al., 2001). 
Price is defined as the amount of money which is chargeable while the goods or service to be delivered or served to the customer (Adebiyi et al., 2016; Kotler et al., 2010). In telecommunication industry context, the price is not limited to the goods such as SIM card, recharge voucher, SMS charge, internet charge, and phone price but also consists of cost maintenance of the relationship between the service provider (Adebiyi et al., 2016). Thus, price is the vital factor which affects customers decision-making process (Chang et al., 2011; Hubert et al., 2001). The accuracy of the billing system is part of the service quality dimensions as it reflects the quality of communication between the company and customer (Lim et al., 2006; Kim et al., 2004; Gerpott et al., 2001).

\section{Conceptual Framework}

The conceptual framework is shown in Figure 4.

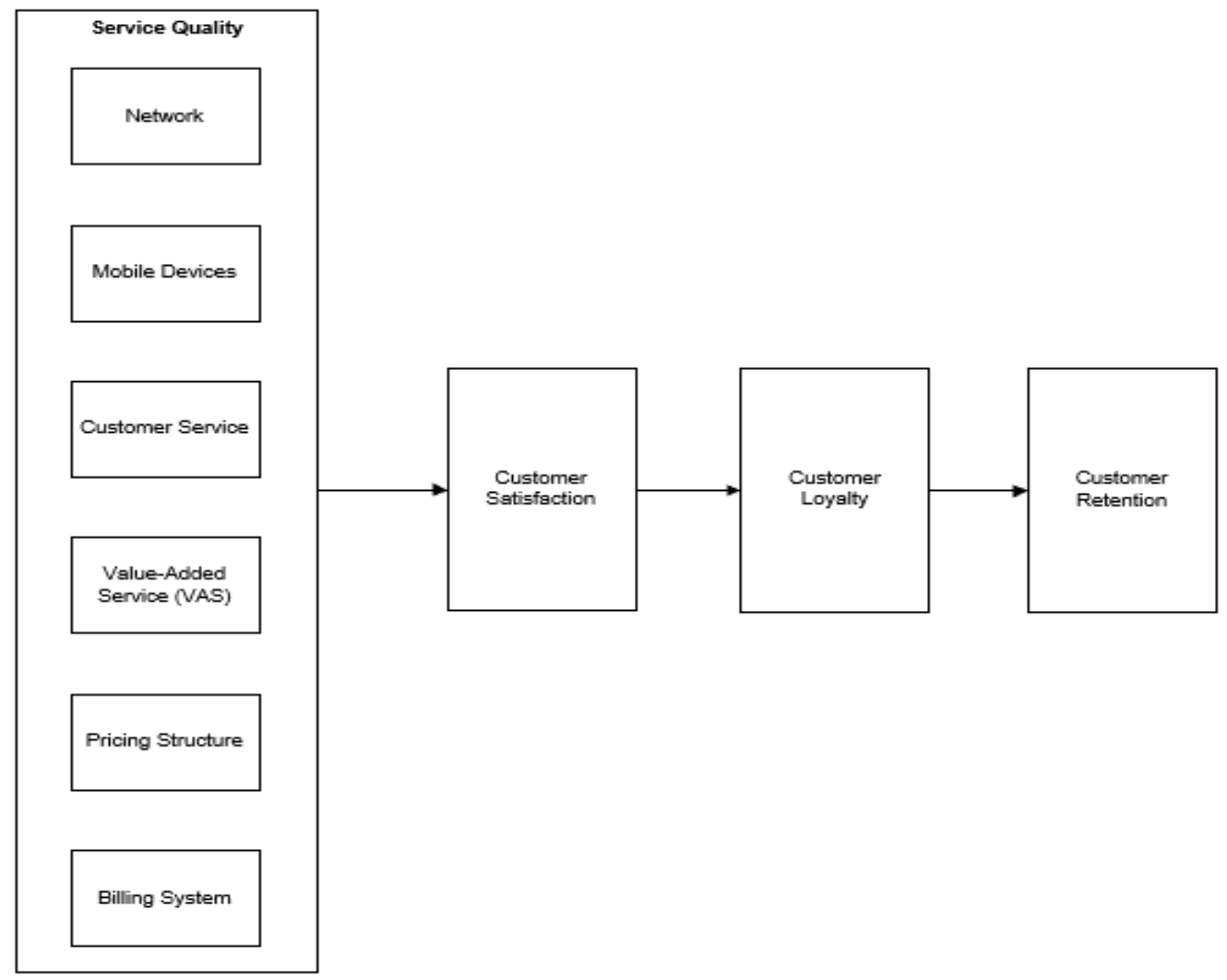

Figure 4: Conceptual Framework

\section{Research Methods}

\section{Sampling frame and data collection}

A non-probability convenience sampling technique was used in this research. Respondents were mobile users. Data were gathered using self-administered questionnaires. The questionnaire contains two sections. In the first section, respondents were requested to answer questions relating to the degree of their satisfaction, loyalty, retention and also the service quality provided by their telco, on a five-point Likert scale, ranging from "strongly agree" to "strongly disagree". In the second section, some demographic questions were gathered.

All items intended to measure the variables in this research were taken from previously validated instruments. The construct of pricing structure, network and billing system was 
measured with scales from Santouridis et al. (2010); Lim et al. (2006); Lee et al. (2001); and Gerpott et al. (2001). The construct of value-added service was measured with scales from Santouridis et al. (2010) and Lim et al. (2006), while the construct of mobile device was measured with scales from Kim et al. (2004). On the other hand, customer service, customer satisfaction, customer loyalty and customer retention were assessed with measures reported by Santouridis et al. (2010); Lim et al. (2006); Kim et al. (2004); Gerpott et al. (2001); Aydin et al. (2005), and Keaveney et al. (1995).

From a total of 150 questionnaires collected, 103 were found as valid and complete, thus yielding a response rate of 68.67 per cent. The questionnaire responses were coded, and the data were entered into the Statistical Package for the Social Sciences (SPSS) Version 24 and Structural Equation Modelling-Partial Least Squares (SEM-PLS) by Ringle (2015).

\section{Respondents' Characteristics}

70 of the respondents were male (68 per cent), and 33 were female ( 32 per cent). The majority of the respondents were in the age of 24-34 years old (45.6 per cent). In addition, the majority of the respondents (45.6 per cent) were Chinese, while 42.6 per cent of respondents were Malay, and there was 3.9 per cent of Indian respondents. In term of education, 64.1 per cent of the respondents have an undergraduate certificate. With regards to the profession and monthly income, most of the respondents were working in the technical industry (47.6 per cent) with monthly income between RM5001 until RM10000 (40.8 per cent). In terms of respondent's package subscription, most of the respondents subscribed to postpaid package (77.7 per cent). With regards to the service provider and device change frequency, most of them (26.2 per cent) were Digi users and changed their device after two years (72.8 per cent) by referring to Table III.

Table III: Overall profile of respondents

\begin{tabular}{|l|l|c|c|}
\hline \multicolumn{2}{|l|}{ Variable } & Frequency & Percentage \\
\hline \multirow{5}{*}{ Gender } & Male & 70 & 68 \\
\cline { 2 - 4 } & Female & 33 & 32 \\
\hline \multirow{5}{*}{ Ethnicity } & Less than 24 years old & 3 & 2.9 \\
\cline { 2 - 4 } & 24 to 34 years old & 47 & 45.6 \\
\cline { 2 - 4 } & 35 to 44 years old & 37 & 35.9 \\
\cline { 2 - 4 } & 45 to 54 years old & 10 & 9.7 \\
\cline { 2 - 4 } & More than 54 years old & 6 & 5.8 \\
\hline \multirow{5}{*}{ Education background } & Malay & 44 & 42.7 \\
\cline { 2 - 4 } & Chinese & 47 & 45.6 \\
\cline { 2 - 4 } & Indian & 4 & 3.9 \\
\cline { 2 - 4 } & Other & 8 & 7.8 \\
\cline { 2 - 4 } & Primary & 7 & 1.0 \\
\cline { 2 - 4 } & Secondary & 66 & 6.8 \\
\cline { 2 - 4 } & Undergraduate & 24 & 23.3 \\
\cline { 2 - 4 } & Postgraduate & 5 & 4.9 \\
\cline { 2 - 4 } & Other & 23 & 22.3 \\
\hline \multirow{5}{*}{ Profession } & Administrative \& Managerial & 5 & 47.6 \\
\cline { 2 - 4 } & Technical & & 4.9 \\
\cline { 2 - 4 } & Sales \& Service & 5 & \\
\hline
\end{tabular}




\begin{tabular}{|c|c|c|c|}
\hline & Education & 9 & 8.7 \\
\hline & Entrepreneur & 2 & 1.9 \\
\hline & Other & 15 & 14.6 \\
\hline \multirow{5}{*}{ Monthly income } & $<$ RM 2000 & 9 & 8.7 \\
\hline & RM 2000 - RM 5000 & 35 & 34.0 \\
\hline & RM 5001 - RM 10000 & 42 & 40.8 \\
\hline & RM 10001 - RM 15000 & 13 & 12.6 \\
\hline & > RM 150001 & 4 & 3.9 \\
\hline \multirow{4}{*}{ Package subscription } & Postpaid & 80 & 77.7 \\
\hline & Prepaid & 21 & 20.4 \\
\hline & Broadband & 1 & 1 \\
\hline & Other & 1 & 1 \\
\hline \multirow{5}{*}{ Service provider } & Maxis & 17 & 16.5 \\
\hline & Celcom & 25 & 24.3 \\
\hline & Digi & 27 & 26.2 \\
\hline & U-Mobile & 22 & 21.4 \\
\hline & Other & 12 & 11.7 \\
\hline \multirow{5}{*}{ Device changes } & $<3$ Months & 3 & 2.9 \\
\hline & 3 Months - 6 Months & 2 & 1.9 \\
\hline & 6.1 Months - 12 Months & 2 & 1.9 \\
\hline & 12.1 Months - 24 Months & 21 & 20.4 \\
\hline & $>24.1$ Months & 75 & 72.8 \\
\hline
\end{tabular}

\section{Data Analysis and Results}

\section{Reliability and validity analysis}

To assess reliability and validity, internal consistency reliability (Cronbach alpha), composite reliability, and the average variance extracted (AVE) analysis were performed. Consistent with the suggestions of Sekaran (2003);Nunnally (1978), Cronbach's alpha and composite reliability for all the items exceeded the standard value of 0.68 and 0.708 , respectively. The average variance extracted (AVE) for all constructs is also higher than the threshold value of 0.5 , as recommended by Fornell \& Larcker (1981). Provided that all three values of reliability were above the suggested threshold limits, the scales for assessing these constructs were considered to exhibit satisfactory convergence reliability. Table IV shows the results of the various measures of reliability and validity tests. 
Table IV: Reliability and validity analysis

Discriminant Validity

\begin{tabular}{|l|c|c|c|c|}
\hline \multicolumn{1}{|c|}{ Construct } & $\begin{array}{c}\text { No. of } \\
\text { Item }\end{array}$ & $\begin{array}{c}\text { Cronbach } \\
\text { Alpha }\end{array}$ & $\begin{array}{c}\text { Composite } \\
\text { Reliability }\end{array}$ & $\begin{array}{c}\text { Average Variance } \\
\text { Extracted (AVE) }\end{array}$ \\
\hline Network & 2 & 0.68 & 0.86 & 0.76 \\
\hline Value-added service & 3 & 0.88 & 0.92 & 0.80 \\
\hline Mobile device & 3 & 0.85 & 0.91 & 0.77 \\
\hline Customer service & 4 & 0.86 & 0.91 & 0.71 \\
\hline Billing system & 3 & 0.80 & 0.89 & 0.71 \\
\hline Pricing structure & 3 & 0.87 & 0.92 & 0.79 \\
\hline Customer satisfaction & 1 & - & - & - \\
\hline Customer loyalty & 2 & 0.84 & 0.93 & 0.86 \\
\hline Customer retention & 1 & - & - & - \\
\hline
\end{tabular}

Fornell and Larcker criterion and Heterotrait-Monotrait (HTMT) ratio of correlations were used to evaluate the discriminant validity test. In Fornell and Larcker criterion, square root of AVE of each latent construct is compared with correlations among constructs whereby discriminant validity will be established if the AVE is larger than the squared correlation coefficients between variables (Fornell, \& Larcker, 1981). On the other hand, the HeterotraitMonotrait (HTMT) ratio of correlations was also performed, whereby an HTMT value below 0.90 is set as a benchmark (Henseler, Ringle, \& Sarstedt, 2015). Referring to Table V and VI, the square root of AVE is higher than the correlations among constructs, and all the constructs have an HTMT value less than 0.90; hence, suggest that the measurement model exhibited good discriminant validity.

\section{Hypotheses Assessment}

To test the significance of the path model, bootstrapping has been performed with 5000 resample, as recommended by Hair et al. (2014). Customer satisfaction was found to have a significant influence on customer loyalty $(\mathrm{H} 1, \beta=0.782, p=0.000)$, network was found to have a significant influence on customer satisfaction ( $\mathrm{H} 2, \beta=0.299, p=0.008)$, customer service and pricing structure were also found to have a significant influence on customer satisfaction ( $\mathrm{H} 5, \beta=0.286, p=0.039 ; \mathrm{H} 6, \beta=0.282, p=0.003$ ). 
INTERNATIONAL JOURNAL OF ACADEMIC RESEARCH IN BUSINESS AND SOCIAL SCIENCES Vol. 10, No. 9, 2020, E-ISSN: 2222-6990 ㄷ 2020 HRMARS

Table V: Fornell-Larcker criterion

\begin{tabular}{|c|c|c|c|c|c|c|c|c|c|}
\hline Construct & $\begin{array}{l}\text { Billi } \\
\text { ng } \\
\text { syst } \\
\text { em }\end{array}$ & $\begin{array}{c}\text { Custo } \\
\text { mer } \\
\text { loyalt } \\
y \\
\end{array}$ & $\begin{array}{l}\text { Custo } \\
\text { mer } \\
\text { retent } \\
\text { ion } \\
\end{array}$ & $\begin{array}{l}\text { Custo } \\
\text { mer } \\
\text { satisfac } \\
\text { tion }\end{array}$ & $\begin{array}{l}\text { Custo } \\
\text { mer } \\
\text { servic } \\
\text { e }\end{array}$ & $\begin{array}{l}\text { Mo } \\
\text { bile } \\
\text { devi } \\
\text { ce }\end{array}$ & $\begin{array}{l}\text { Netw } \\
\text { ork }\end{array}$ & $\begin{array}{l}\text { Pricin } \\
\text { g } \\
\text { struct } \\
\text { ure }\end{array}$ & $\begin{array}{l}\text { Value- } \\
\text { added } \\
\text { service }\end{array}$ \\
\hline Billing system & $\begin{array}{c}0.84 \\
4\end{array}$ & & & & & & & & \\
\hline $\begin{array}{l}\text { Customer } \\
\text { loyalty }\end{array}$ & $\begin{array}{c}0.50 \\
5\end{array}$ & 0.927 & & & & & & & \\
\hline $\begin{array}{l}\text { Customer } \\
\text { retention }\end{array}$ & $\begin{array}{c}0.05 \\
5\end{array}$ & -0.192 & - & & & & & & \\
\hline $\begin{array}{l}\text { Customer } \\
\text { satisfaction }\end{array}$ & $\begin{array}{c}0.46 \\
2\end{array}$ & 0.782 & -0.117 & - & & & & & \\
\hline $\begin{array}{l}\text { Customer } \\
\text { service }\end{array}$ & $\begin{array}{c}0.76 \\
8\end{array}$ & 0.645 & -0.073 & 0.589 & 0.843 & & & & \\
\hline Mobile device & $\begin{array}{c}0.29 \\
1\end{array}$ & 0.300 & -0.150 & 0.250 & 0.358 & $\begin{array}{c}0.87 \\
9\end{array}$ & & & \\
\hline Network & $\begin{array}{c}0.45 \\
6\end{array}$ & 0.550 & -0.072 & 0.576 & 0.529 & $\begin{array}{c}0.33 \\
2\end{array}$ & $\begin{array}{c}0.87 \\
0\end{array}$ & & \\
\hline $\begin{array}{l}\text { Pricing } \\
\text { structure }\end{array}$ & $\begin{array}{c}0.47 \\
7\end{array}$ & 0.587 & -0.054 & 0.527 & 0.493 & $\begin{array}{c}0.21 \\
3\end{array}$ & 0.340 & 0.888 & \\
\hline $\begin{array}{l}\text { Value-added } \\
\text { service }\end{array}$ & $\begin{array}{c}0.60 \\
0\end{array}$ & 0.559 & -0.138 & 0.550 & 0.640 & $\begin{array}{c}0.40 \\
3\end{array}$ & 0.543 & 0.385 & 0.895 \\
\hline
\end{tabular}

Table VI: Heterotrait-Monotrait ratio (HTMT)

\begin{tabular}{|l|c|c|c|c|c|c|c|c|}
\hline \multicolumn{1}{|c|}{ Construct } & $\begin{array}{c}\text { Billing } \\
\text { system }\end{array}$ & $\begin{array}{c}\text { Customer } \\
\text { loyalty }\end{array}$ & $\begin{array}{c}\text { Customer } \\
\text { retention }\end{array}$ & $\begin{array}{c}\text { Customer } \\
\text { satisfaction }\end{array}$ & $\begin{array}{c}\text { Customer } \\
\text { service }\end{array}$ & $\begin{array}{c}\text { Mobile } \\
\text { device }\end{array}$ & Network & $\begin{array}{c}\text { Pricing } \\
\text { structure }\end{array}$ \\
\hline $\begin{array}{l}\text { Customer } \\
\text { loyalty }\end{array}$ & 0.618 & & & & & & & \\
\hline $\begin{array}{l}\text { Customer } \\
\text { retention }\end{array}$ & 0.059 & 0.21 & & & & & & \\
\hline $\begin{array}{l}\text { Customer } \\
\text { satisfaction }\end{array}$ & 0.508 & 0.854 & 0.117 & & & & & \\
\hline $\begin{array}{l}\text { Customer } \\
\text { service }\end{array}$ & 0.837 & 0.758 & 0.076 & 0.629 & & & & \\
\hline Mobile device & 0.357 & 0.352 & 0.158 & 0.27 & 0.409 & & & \\
\hline Network & 0.634 & 0.717 & 0.082 & 0.689 & 0.685 & 0.423 & & \\
\hline Pricing structure & 0.557 & 0.687 & 0.061 & 0.552 & 0.569 & 0.254 & 0.442 & \\
\hline $\begin{array}{l}\text { Value-added } \\
\text { service }\end{array}$ & 0.723 & 0.655 & 0.148 & 0.587 & 0.736 & 0.459 & 0.683 & 0.43 \\
\hline
\end{tabular}


Table VII: Summary of hypotheses testing

\begin{tabular}{|c|l|c|c|c|}
\hline Hypothesis & \multicolumn{1}{|c|}{ Relationship } & $\begin{array}{c}\text { Path } \\
\text { Coefficient }\end{array}$ & $p$-Value & Decision \\
\hline H1 & $\begin{array}{l}\text { Customer satisfaction } \rightarrow \\
\text { Customer loyalty }\end{array}$ & 0.782 & 0.000 & Accept \\
\hline H2 & $\begin{array}{l}\text { Network } \rightarrow \text { Customer } \\
\text { satisfaction }\end{array}$ & 0.299 & 0.008 & Accept \\
\hline H3 & $\begin{array}{l}\text { Value-added service } \rightarrow \\
\text { Customer satisfaction }\end{array}$ & -0.195 & 0.121 & Reject \\
\hline H4 & $\begin{array}{l}\text { Mobile devices } \rightarrow \\
\text { Customer satisfaction }\end{array}$ & -0.052 & 0.592 & Reject \\
\hline H5 & $\begin{array}{l}\text { Customer service } \rightarrow \\
\text { customer satisfaction }\end{array}$ & 0.286 & 0.039 & Accept \\
\hline H6 & $\begin{array}{l}\text { Pricing structure } \rightarrow \\
\text { Customer satisfaction }\end{array}$ & 0.282 & 0.003 & Accept \\
\hline H7 & $\begin{array}{l}\text { Billing system } \rightarrow \text { Customer } \\
\text { satisfaction }\end{array}$ & -0.130 & 0.320 & Reject \\
\hline H8 & $\begin{array}{l}\text { Customer loyalty } \rightarrow \\
\text { Customer Retention }\end{array}$ & -0.192 & 0.134 & Reject \\
\hline
\end{tabular}

Coefficients determination (R2) and effect size

To measure the predictive accuracy of the model, the coefficient determination $\left(R^{2}\right)$ was performed. $\mathrm{R}^{2}$ represents the proportion of the variance in the dependent variable that is predictable from the independent variable, whereby the higher value is recommended, and represent a higher amount of the variance in the data. As shown in Table VIII, customer satisfaction can explain 52.3 per cent of the variations of customer loyalty. Customer loyalty able to explain 3.7 per cent of the variations of retention while service quality able to explain 5. per cent of the variations of customer satisfaction.

Table VIII: Coefficient Determination $\left(R^{2}\right)$

\begin{tabular}{|l|c|}
\hline \multicolumn{1}{|c|}{ Construct } & $\mathbf{R}^{\mathbf{2}}$ \\
\hline Customer loyalty & 0.612 \\
\hline Customer retention & 0.037 \\
\hline Customer satisfaction & 0.523 \\
\hline
\end{tabular}

Effect size $\left(f^{2}\right)$ is another criterion used to evaluate the structural model that examines the unique effect of each independent variable on the dependent variable. According to Cohen (1988), $\mathrm{f}^{2}$ value of $0.02,0.15$ and 0.35 is classified as small, medium and large, respectively. As shown in Table IX, the effect sizes of customer satisfaction towards customer loyalty, was big while the other relationship has small effects. Hence, it is concluded that the research has an adequate predictive relevance. 
Table IX: Effect size $\left(\mathrm{f}^{2}\right)$

\begin{tabular}{|l|c|}
\hline \multicolumn{1}{|c|}{ Construct } & $\mathbf{f}^{\mathbf{2}}$ \\
\hline Customer loyalty $\rightarrow$ Customer satisfaction & 0.013 \\
\hline Customer satisfaction $\rightarrow$ Customer loyalty & 1.576 \\
\hline Customer service $\rightarrow$ customer satisfaction & 0.057 \\
\hline Mobile device $\rightarrow$ Customer Satisfaction & 0.005 \\
\hline Network $\rightarrow$ Customer Satisfaction & 0.120 \\
\hline Pricing structure $\rightarrow$ Customer Satisfaction & 0.121 \\
\hline Value-added service $\rightarrow$ Customer Satisfaction & 0.039 \\
\hline
\end{tabular}

\section{Discussion and Conclusion}

\section{Discussion}

This research aims to answer three research questions. Eight hypotheses were formed. The results of this research are deliberated below and summarized in Table $X$.

RQ1: Does service quality has a significant relationship with customer satisfaction?

RQ1 aims to investigate the relationship between service quality and customer satisfaction. Six hypotheses were formed, and three were accepted. From the analysis, the results show the network has a significant effect on customer satisfaction. This outcome is agreeable from some extant research whereas Shafei et al. (2016); Lim et al. (2006); and Gerpott et al. (2001) who was conducted a research in Egypt, United States, and German telecommunication market respectively. Following that, customer service and pricing structure were also found to have a significant effect on customer satisfaction. These two constructs found to be a significant influence to the customer satisfaction from previous research such as Shafei et al. (2016); Santouridis et al. (2010); and Ali et al. (2010) whereby those researches were from Egypt market, Greece mobile telephony market, and Pakistan mobile market. Apart from that, Nigeria GSM market had been examined by Adeleke et al. (2012) concluded that pricing and customer service/care have significantly influenced customer satisfaction. The same results that had highlighted by Munyanti \& Masrom (2018). Value-added services, mobile devices, and billing system has been found to have an insignificant effect. The insignificant effect can be explained due to the different perceptions, expectation, and fulfilments customer toward the service provided by the company.

RQ2: Does customer satisfaction has a significant relationship with customer loyalty?

This research has found that customer satisfaction has a positive and significant relationship to customer loyalty. This finding is similar to Shafei et al. (2016), Santouridis et al. (2010), Kim et al. (2004), Lim et al. (2006), Aydin et al. (2005), Gerpott et al. (2001) and Lee et al. (2001). Therefore, as customer satisfied with the service provided by the company, they will loyal towards the company.

RQ3: Does customer loyalty has a significant relationship with customer retention?

Customer loyalty has been found to have no significant influence on customer retention. This finding is interesting because despite the customer consistently respond favourably toward a brand or the company, and they will not retain to the same company. The finding of this research differs from Danish et al. (2015), who found a significant relationship between customer loyalty and customer retention. 
Table X: Summary of research question \& hypothesis mapping

\begin{tabular}{|c|c|c|}
\hline \multicolumn{3}{|c|}{ Research objective and hypothesis mapping } \\
\hline Research objective & Hypothesis & Decision \\
\hline $\begin{array}{l}\text { RQ1: Does service quality has a significant } \\
\text { relationship with customer satisfaction? }\end{array}$ & $\begin{array}{l}\mathrm{H} 2, \mathrm{H} 3, \mathrm{H} 4, \\
\mathrm{H} 5, \mathrm{H} 6 \text {, and } \\
\mathrm{H} 7\end{array}$ & $\begin{array}{l}\text { H2: Accept } \\
\text { H3: Reject } \\
\text { H4: Reject } \\
\text { H5: Accept } \\
\text { H6: Accept } \\
\text { H7: Reject }\end{array}$ \\
\hline $\begin{array}{l}\text { RQ2: Does customer satisfaction has a } \\
\text { significant relationship with customer loyalty. }\end{array}$ & $\mathrm{H} 1$ & H1: Accept \\
\hline $\begin{array}{l}\text { RQ3: Does customer loyalty has a significant } \\
\text { relationship with customer retention. }\end{array}$ & H8 & H8: Reject \\
\hline
\end{tabular}

\section{Research Implication and Suggestion}

This research gives several implications for telecommunication companies. As service quality is important for the customer, they shall focus on network quality enhancement. Apart from that, competitive price plays a crucial role in retaining the customer. Thus, it's necessary to look into how to strategically the pricing structure for the products and services. Royalty programs-rewards, promotions, customer service improvement plan, network quality improvement plan, maintain the existing equipment for ensuring its functionality still in optimum stage, and replacement package for obsolete equipment is suggested to retain existing customers. Besides, the company need to ensure their customer representative in the service department is well-trained to maintain customer service quality.

\section{References}

Adebiyi, S. O., Shitta, H. A., \& Olonade, O. P. (2016). Determinants of customer preference and satisfaction with Nigerian mobile telecommunication services. BVIMSR's Journal of Management Research, 8(1), 1.

Adeleke, A., \& Suraju, A. A. (2012). The determinants of customer loyalty in Nigeria's GSM market. International Journal of Business and Social Science, 3(14).

Ali, J. F., Ali, I., Rehman, K., Yilmaz, A., Safwan, N., and Afzal, H. (2010). Determinants of consumer retention in the cellular industry of Pakistan. African Journal of Business Management, Vol. 4 No. 12, pp 2402-2408.

Arokiasamy, A. R. A., \& Abdullah, A. G. (2013). Service quality and customer satisfaction in the cellular telecommunication service provider in Malaysia. Researchers World, 4(2), 1.

Aydin, S., \& Özer, G. (2005). The analysis of antecedents of customer loyalty in the Turkish mobile telecommunication market. European Journal of Marketing, 39(7/8), 910-925.

Bernama. (2008). Handphone Users can now switch service providers without having to change the number.

http://www.bernama.com/bernama/v5/bm/newsindex.php?id=364791. 
Chang, P. K., \& Chong, H. L. (2011). Customer satisfaction and loyalty on service provided by Malaysian telecommunication companies. In Proceedings of the 2011 International Conference on Electrical Engineering and Informatics (pp. 1-6). IEEE.

Chuah, H. W., \& Mohd F., H. (2011). Exploring service quality, customer satisfaction and customer loyalty in the Malaysian mobile telecommunication industry. In 2011 IEEE Colloquium on Humanities, Science and Engineering (pp. 733-738). IEEE.

Chuah, H. W., Marimuthu, M., \& Ramayah, T. (2015). Wireless telecommunications industry in Malaysia: Trends, challenges, and opportunities. In consumption in Malaysia: Meeting of new changes. Universiti Sains Malaysia Publisher, Penang.

Cronbach, R. G. (1960), Essential of psychological testing, 2nd ed. Harper and Row Company, New York, NY.

Danish, R. Q., Ahmad, F., Ateeq, A., Ali, H. Y., \& Humayon, A. A. (2015). Factors affecting customer retention in telecommunication sector of Pakistan. American Journal of Marketing Research, 1(2), 28-36.

Domb, M., Sujata, J., Sanjay, B., Arindam, R., \& Jypti, S. (2016). An empirical study to measure customer experience for telecommunication operators in Indian telecommunication industry. GSTF Journal on Business Review (GBR), 4(2).

Hubert, A., Harmanm, and Wricke, M. (2001). Customer satisfaction as an antecedent of price acceptance: Results of empirical study. Journal of Product and Brand Management, vol. 10 (3), pp. 160-169.

Fornell, C. A. L. D. F. (1981). Evaluating structural equation models with unobservable variables and measurement error. Journal of Marketing Research [online] 18(1): 39 available from <http://www.jstor.org/stable/3151312?origin=crossref $>$.

Hair, J. F. J., Hult, G. T. M., Ringle, C., and Sarstedt, M. (2014). A primer on partial least squares structural equation modelling (PLS-SEM), [online] vol. 46. Available from $<$ http://linkinghub.elsevier.com/retrieve/pii/S0024630113000034>.

Hair, J. F., Sarstedt, M., Ringle, C. M., and Mena, J. A. (2012). An assessment of the use of partial least squares structural equation modelling in marketing research. Journal of the Academy of Marketing Science 40(3): 414-433.

Haque, A., Ahmed, I., \& Rahman, S. (2007). Exploring critical factors for choice of mobile service providers and its effectiveness on Malaysian consumers. Journal of International Business and Economics, 2(2), 84-96.

Henseler, J., Ringle, C. M., and Sarstedt, M. (2014). "A new criterion for assessing discriminant validity in variance-based structural equation modelling. Journal of the Academy of Marketing Science. 43(1), 115-135.

Keaveney, S. M. (1995). Customer switching behavior in service industries: An exploratory study. Journal of marketing, 59(2), 71-82.

Khaligh, A. A., Miremadi, A., \& Aminilari, M. (2012). The impact of eCRM on loyalty and retention of customers in Iranian telecommunication sector. International Journal of Business and Management, 7(2), 150.

Khan, I. (2012). Impact of customer satisfaction and retention on customer loyalty. International Journal of Scientific \& Technology Research, 1(2), 106-110.

Kim, M. K., Park, M. C., \& Jeong, D. H. (2004). The effects of customer satisfaction and switching barrier on customer loyalty in Korean mobile telecommunication services. Telecommunications policy, 28(2), 145-159.

Kotler, P., \& Armstrong, G. (2010). Principles of marketing. Pearson education. 
Lee, J., Lee, J., \& Feick, L. (2001). The impact of switching costs on the customer satisfactionloyalty link: mobile phone service in France. Journal of services marketing, 15(1), 3548.

Lim, H., Widdows, R., \& Park, J. (2006). M-loyalty: winning strategies for mobile carriers. Journal of consumer Marketing, 23(4), 208-218.

Loke, S. P., Taiwo, A. A., Salim, H. M., Downe, A. G., \& Petronas, U. T. (2011). Service quality and customer satisfaction in a telecommunication service provider. In International conference on financial management and economics (Vol. 11, No. 2, pp. 23-29).

Malaysian Communications and Multimedia Commission (MCMC). (2008). http://skmm.gov.my/consumer/pdf/YB_MINISTER_MNP_pr.pdf.

Malaysian Communications and Multimedia Commission (SKMM). (2018). Connectivity key to digital transformation industry performance report 2018.

Mohamad, N. (2004). Productivity growth in the Malaysian mobile telecommunications industry. International Journal of Economics, Management and Accounting, 12(2).

Ndubisi, N. O. (2005). Customer loyalty and antecedents: a relational marketing approach. In Allied Academies international conference. Academy of marketing studies. Proceedings (Vol. 10, No. 2, p. 49). Jordan Whitney Enterprises, Inc.

Nunnally, J. C. (1978). Psychometric theory (2nd ed). New York, Oliver: McGraw-Hill.

Ocloo, C. E., \& Tsetse, E. K. (2013). Customer retention in the Ghanaian mobile telecommunication industry. European journal of business and social sciences, 2(7), 136-160.

Oladapo, K., Omotosho, O., \& Adeduro, O. (2018). Predictive analytics for increased loyalty and customer retention in telecommunication industry. Int J Comput Appl, 975, 8887.

Otaigbe, E. E. (2018). Exploring satisfaction and retention strategies for generation y customers. (10811453 D.B.A.), Walden University, Ann Arbor. Retrieved from https://vpn.utm.my/docview/2038445392?accountid=41678 ProQuest Dissertations \& Theses Global database.

Pan, Y., Sheng, S., \& Xie, F. T. (2011). Antecedent of customer loyalty: An empirical synthesis and reexamination, Journal of retailing and customer services, doi:10.1016/j.jretcons.

Preikschas, M. W., Cabanelas, P., Rudiger, K., \& Lampon, J. F. (2017). Value cocreation, dynamic capabilities and customer retention in industrial markets. Journal of Business \& Industrial Marketing, 32, 409-420. doi:10.1108/JBIM-102014-0215.

Ringle, C. M., Wende, S., and Becker, J.-M. (2015). "SmartPLS 3." Boenningstedt: SmartPLS $\mathrm{GmbH}$, http://www.smartpls.com.

Ronald, W. (2016). Customer retention is highly saturated in telco market. (Doctorate of Business Administration), Northcentral University, Prescott Valley, Arizona.

Santouridis, I., \& Trivellas, P. (2010). Investigating the impact of service quality and customer satisfaction on customer loyalty in mobile telephony in Greece. The TQM Journal, 22(3), 330-343.

Shafei, I., \& Tabaa, H. (2016). Factors affecting customer loyalty for mobile telecommunication industry. EuroMed Journal of Business, 11(3), 347-361.

Silva, K., \& Yapa, S. (2013). Customer retention: with special reference to telecommunication industry in Sri Lanka.

Torsten, J. G., Rams, W., \& Schindler, A. (2001). Customer retention, loyalty, and satisfaction in the German mobile cellular telecommunication market. 
Wirtz, J. (2003). Halo in Customer satisfaction measures: The role of purpose of rating, number of attributes and customer involvement. International Journal of Service Industry Management, 14(1), 96-119.

Zeithaml, V. A., Berry, L. L., \& Parasuraman, A. (1996). The behavioural consequences of service quality. Journal of marketing, 60(2), 31-46. 